\title{
Phage Adsorption and Cell Adherence Are Motility-dependent Characteristics of the Gliding Bacterium Cytophaga johnsonae
}

\author{
By RICHARD H. WOLKIN AND JACK L. PATE* \\ Department of Bacteriology, University of Wisconsin, Madison, WI 53706, USA
}

(Receited 5 August 1985)

\begin{abstract}
Mutants of the gliding bacterium Cytophaga johnsonae that are incapable of movement are called truly nonmotile (TNM) to distinguish them from other mutants that are motile but produce nonspreading colonies. All TNM mutants are pleiotropic, being nonmotile, unable to digest chitin, resistant to all phages that infect wild-type cells, nonadherent and having less hydrophobic surfaces than do wild-type cells. In this study, we tested the idea that the TNM pleiotropy is the result of blocking cell surface movement, rather than of loss or alteration of a specific cell surface component. Motility of wild-type cells was blocked by addition of chemicals, and treated cells were compared with untreated cells for their ability to adhere to spheroidal hydroxyapatite (SHA) beads and to adsorb phages, two characteristics used as an index of the TNM pleiotropy. All the chemicals tested that blocked motility also reduced phage adsorption and adherence to SHA to approximately the same extent seen with TNM mutants. The chemicals tested (carbonyl cyanide $m$-chlorophenylhydrazone, cyanide, azide and photoactivated eosin $Y$ and rose bengal) were sufficiently different from each other to reduce the possibility that each chemical inhibited phage adsorption and cell adherence by similar secondary effects, independent of their effects on motility. It was also shown that the pleiotropy of TNM mutants is not caused by their inability to maintain a membrane potential. The results are compatible with the conclusion that the TNM pleiotropy is manifested whenever cell movement is stopped, whether by mutation or by use of chemical inhibitors, and they are inconsistent with the idea that all TNM mutants are pleiotropic because they all carry a lesion in the same gene that codes for expression of surface components required for all characteristics affected. The reason that stopping motility influences several seemingly unrelated properties is not known but is probably related to adaptations required for the organism to interact with its environment through a cell surface covered with a slime that is normally kept in motion by components of the machinery of gliding motility.
\end{abstract}

\section{INTRODUCTION}

Wild-type cells of the gliding bacterium Cytophaga johnsonae make translocational, pivoting and spinning movements when attached to a glass microscope slide, are capable of moving latex microspheres over their entire surfaces, and produce spreading colonies on agar gels. Cells of one class of nonspreading mutants never move under any conditions tested and do not move latex microspheres over their cell surfaces. This class of mutants is therefore referred to as truly nonmotile (TNM) mutants (Chang et al., 1984). An unusual pleiotropy, referred to as the TNM pleiotropy, is associated with these mutants. In addition to being nonmotile, cells of TNM mutants are incapable of chitin digestion, are resistant to all phages to which wild-type cells are sensitive, have less hydrophobic cell surfaces and are less adherent than are wild-type cells (Chang et al., 1984; Wolkin \& Pate, 1985).

Abbreviations: $\mathrm{CCCP}$, carbonyl cyanide $m$-chlorophenylhydrazone; EC, enriched cytophaga; PB, potassium phosphate buffer; p.m.f., proton-motive force; SHA, spheroidal hydroxyapatite; TNM, truly nonmotile. 
Studies of over 250 independently isolated TNM mutants suggested that anything that stops motility invariably results in the TNM pleiotropy, not because of alteration or loss of a specific cell component or inability to supply an intermediate required for expression of all affected characteristics, but because motility itself is required for their expression (Pate et al., 1979; Chang et al., 1984; Wolkin \& Pate, 1985). In the present work, we tested this idea by determining whether chemicals that stop motility of wild-type cells confer the TNM pleiotropy on wild-type cells. Specifically, we asked if chemically treated (nonmotile) wild-type cells behave like cells of TNM mutants in exhibiting decreased phage adsorption and decreased adherence to spheroidal hydroxyapatite (SHA) beads. We also tested the ability of treated (nonmotile) and untreated (motile) wild-type cells and cells of a TNM mutant to generate a membrane potential.

\section{METHODS}

Organisms. Cytophaga johnsonae strain UW' 101 is our laboratory strain derived from a single colony of $C$. johnsonae ATCC 17061. C. johnsonae strain UW 1029 is a TNM mutant derived from strain UW101 by selection for nonadherence to cheesecloth (Wolkin \& Pate, 1985). The two phages used in this study were isolated by phageenrichment procedures using $C$. johnsonae strain UW10l and propagated on that strain as described previously (Pate et al., 1979; Wolkin \& Pate, 1984).

Chemicals and reagents. Rose bengal, eosin $\mathrm{Y}$, gramicidin, carbonyl cyanide $m$-chlorophenylhydrazone (CCCP) and sodium cyanide were obtained from Sigma. Sodium azide was obtained from Eastman Organic Chemical, and 3,3'-dipropylthiadicarbocyanine iodine ( $\mathrm{diSC}_{3}$ ) was purchased from Molecular Probes Inc., Plano, Tx., USA. SHA beads were purchased from Gallard-Schlessinger Chemical Corp. Silicone oil (Dexter Hysol 550 and Dexter Hysol 556, 65:35) was purchased from Dexter Olean, NY, USA. $\left[{ }^{1+} \mathrm{C}\right]$ Glucose, $\left[{ }^{14} \mathrm{C}\right]$ salicylic acid, $\left[{ }^{3} \mathrm{H}\right]$ tetraphenylphosphonium bromide $\left.\left({ }^{3} \mathrm{H}\right] \mathrm{TPP}^{+}\right)$and Aquassure were purchased from New England Nuclear.

Medium. Cells were routinely grown at $25^{\circ} \mathrm{C}$ in enriched cytophaga (EC) medium (Glaser \& Pate, 1973), which contained, per litre of distilled water, $2.0 \mathrm{~g}$ tryptone, $0.5 \mathrm{~g}$ yeast extract, $0.5 \mathrm{~g}$ beef extract and $0.2 \mathrm{~g}$ sodium acetate.

Preparation of bacteria for experiments to determine motility, phage adsorption, measurement of membrane potential and glucose accumulation. Cells from late exponential growth $\left(80-90 \mathrm{Klett}\right.$ units, $\left.1.8-2.2 \times 10^{9} \mathrm{cells} \mathrm{ml}^{-1}\right)$ in EC broth grown at $25^{\circ} \mathrm{C}$ were centrifuged for $10 \mathrm{~min}$ at $10000 \mathrm{~g}$ using a Sorvall refrigerated $\left(4^{\circ} \mathrm{C}\right)$ centrifuge. After discarding the supernatant solution, the pellet was washed by resuspension in $5 \mathrm{ml}$ ice-cold potassium phosphate buffer (PB; $5 \mathrm{~mm}, \mathrm{pH} 7 \cdot 1)$ and centrifuged again. After washing again, and unless indicated otherwise, the final pellet was suspended in PB to 50 Klett units $\left(1.2 \times 10^{9}\right.$ cells ml $\left.^{-1}\right)$.

Test for motility. Hanging-drop suspensions of cells were examined by phase-contrast microscopy before and after the various treatments. In such preparations, untreated wild-type cells attach to the cover glass, and most cells in any field move rapidly and continuously. Treated cells were considered to be nonmotile if examination of several fields showed no moving cells.

Adherence assays. We previously used an assay measuring adherence of cells to fragmented cheesecloth suspended in an aqueous buffer to show that cells of TNM mutants were less adherent than cells of their motile parental strain (Wolkin \& Pate, 1985). Preliminary experiments (data not shown) showed that motility-inhibited wild-type cells (treated with chemical inhibitors) behave like TNM mutants in adherence to cheesecloth, but, because cheesecloth is not a uniform material, such assays give limited information. We therefore compared adherent properties of treated and untreated cells by measuring adherence of cells to SHA, as used by Celesk \& London (1980) to compare adherence of cells of strains of oral Cytophaga sp. The uniform nature of the substrate (SHA beads) gives values that are less variable from one experiment to another and that can be compared with results obtained by other researchers measuring adherence properties of other bacteria. The assay used here is similar to that first described by Clark et al. (1978), and the conditions allowed equilibrium between attached and free untreated wild-type cells to be achieved within a $10 \mathrm{~min}$ incubation period. Untreated wild-type cells remained actively motile during the entire assay procedure. Cells were grown to late exponential phase at $25^{\circ} \mathrm{C}$ in $25 \mathrm{ml} \mathrm{EC}$ broth to which $\mathrm{D}-\left[{ }^{14} \mathrm{C}\right] \mathrm{glucose}$ was added to $0.5 \mu \mathrm{Ci}(18.5 \mathrm{kBq}) \mathrm{ml}^{-1}$ with carrier glucose $(0.1 \mathrm{mM}$ final concentration). Cells were centrifuged $(10000 \mathrm{~g})$ for $10 \mathrm{~min}$ at $4^{\circ} \mathrm{C}$. After discarding the supernatant solution, the pellet was washed by resuspension in $25 \mathrm{ml}$ ice-cold $\mathrm{PB}(5 \mathrm{mM}, \mathrm{pH} 7 \cdot 1)$ and centrifuged again. The wash was repeated once more, and the pellet was suspended in PB to the desired cell concentration. For each experimental condition used, cell adherence was measured in three independent experiments. For some assays washed cells were treated with chemicals to inhibit their motility (monitored by phase-contrast microscopy) before measuring their adherence to SHA beads. The SHA beads were washed twice with PB before use in the adherence assays. A $1 \mathrm{ml}$ sample of a cell suspension was added to a measured amount of SHA $(40 \mathrm{mg})$, and this mixture was incubated at $25^{\circ} \mathrm{C}$ with constant gentle mixing using a Uni-Mixer (Lab-Line Instruments) for $10 \mathrm{~min}$, unless indicated otherwise. Preliminary experiments using increased ratios of SHA beads to cells allowed a greater percentage of 
cells to adhere to beads, but longer incubation periods were required for equilibration and there was greater variability in the results obtained. After incubation, the mixture was allowed to stand for approximately $60 \mathrm{~s}$ to allow SHA beads with attached cells to settle, and a $200 \mu \mathrm{l}$ sample of the supernatant fluid was removed and placed in a scintillation vial to determine the number of free cells. The remaining supernatant fluid was removed, and the beads were washed three times with PB and transferred to scintillation vials in $0.5 \mathrm{ml} P B$. Standard curves were prepared by determining the radioactivity of known numbers of ${ }^{1+} \mathrm{C}$-labelled bacterial cells which had been placed in $4.5 \mathrm{ml}$ Aquassure in scintillation vials and counted in a Packard Tricarb 4530 scintillation spectrometer. The numbers of free and attached cells were determined by measuring the radioactivity associated with the particles and that remaining in the supernatant fluid and comparing the measured radioactivity with the appropriate standard curve.

Phage adsorption. Adsorption of phages $\phi \mathrm{Cj} 13$ and $\phi \mathrm{Cj} 54$ to cells was followed by determining over $60 \mathrm{~min}$ the number of free phages remaining in the supernatant solutions after centrifugation of phage-cell suspensions. Phages were added to cell suspensions at a multiplicity of infection of approximately $0 \cdot 1$. Samples of $0 \cdot 1 \mathrm{ml}$ were removed, diluted in ice-cold $5 \mathrm{~mm}-\mathrm{MgCl}_{2}$ and immediately centrifuged for 4 min using an Eppendorf microfuge. Unless otherwise indicated, samples were taken immediately after addition of phages and after 15, 30, 45 and $60 \mathrm{~min}$ incubation at $25^{\circ} \mathrm{C}$. Supernatant solutions of the centrifuged samples were diluted appropriately and the phage titre was determined. Pseudo first-order rate constants, calculated as $\ln 2\left(t_{1 / 2}\right)^{-1}$, were used for comparing adsorption experiments. The term $t_{1 / 2}$ represents the time required for adsorption of one-half of the phages added to each cell suspension.

Measurement of membrane potential. (i) Radioactive probes. Chang (1982) using the lipophilic cation $\left[{ }^{3} \mathrm{H}\right] \mathrm{TPP}+$ as a probe for electrical potential in a flow-dialysis system, demonstrated an electrical potential in wild-type cells of $C$. johnsonae but not in TNM mutant cells. Since the TNM mutants tested exhibited the same growth rates and growth yields as those of wild-type cells, Chang (1982) reasoned that TNM cells must maintain an electrical potential which could not be detected using the flow-dialysis system with $\left[{ }^{3} \mathrm{H}\right] \mathrm{TPP}+$ as a probe, and he suggested that nonmotile cells were less permeable than wild-type cells to the lipophilic cation. Because of these results, we could not use the flow-dialysis system to determine membrane potential in TNM and chemically treated wild-type cells. A modification of the procedure of Kashket \& Barker (1977) was used here in attempts to measure membrane potentials of wild-type cells and cells of the TNM strain UW 1029. The weak acid $\left[{ }^{14} \mathrm{C}\right]$ salicylic acid was used as a $\triangle \mathrm{pH}$ probe, and $\left[{ }^{3} \mathrm{H}\right] \mathrm{TPP}{ }^{+}$was used as an electrical potential probe. We reasoned that if TNM mutants take up the lipophilic cation at a slower rate than do wild-type cells, then allowing longer time periods for passage of TPP ${ }^{+}$into the cells might permit measurement of electrical potential by this method. Radioactive probes were added to an $8 \mathrm{ml}$ cell suspension prepared as described above. After incubating the suspension for $10 \mathrm{~min}$ at $25^{\circ} \mathrm{C}$, three $1 \mathrm{ml}$ samples were removed, each was layered onto $0.5 \mathrm{ml}$ silicone oil in a microfuge tube, and centrifuged for $3 \mathrm{~min}$ in an Eppendorf microfuge. CCCP was added ( $10 \mu \mathrm{M}$ final concentration) to the remaining cell suspension to dissipate the proton-motive force (p.m.f.) and, after an additional 10 min incubation period, three $1 \mathrm{ml}$ samples were removed and each was centrifuged through $0.4 \mathrm{ml}$ silicone oil as before. A $100 \mu l$ sample was removed from the upper aqueous layer of each tube and placed into a scintillation vial. The remaining upper aqueous layers and silicone oil layers were removed from the microfuge tubes, and the bottoms of the plastic tubes containing the cell pellets were cut off and dropped into separate scintillation vials. To each scintillation vial $4.5 \mathrm{ml}$ Aquassure was added and the radioactivity in each vial was determined using a Packard Tricarb 4530 scintillation spectrometer programmed with a pre-determined quench curve and operating using an external standard ratio.

(ii) Fluorescent probe. The accumulation of cyanine dyes by cells is dependent upon the electrical potential of the cells and leads to a quenching of the fluorescence of these dyes (Waggoner, 1979). The presence or absence of an electrical potential in treated and untreated wild-type cells, and in TNM cells was determined using the fluorescent probe $\mathrm{diSC}_{3}$ as follows. Late exponential phase cells were prepared as described above, except that the final pellet was suspended in ice-cold PB such that a $1: 10$ dilution was approximately $85 \mathrm{Klett}$ units $\left(2 \cdot 0 \times 10^{9}\right.$ cells $\left.\mathrm{ml}^{-1}\right)$. PB $(2 \mathrm{ml})$ was added to a quartz cuvette placed in a Varian SF-300 spectrofluorometer. The cuvette was maintained at $25^{\circ} \mathrm{C}$ and its liquid contents were stirred continuously. The $\mathrm{diSC}_{3}$ was added to a final concentration of $1 \mu \mathrm{g} \mathrm{ml}^{-1}$. The diSC $\mathrm{C}_{3}$ fluorescence was excited at $655 \mathrm{~nm}$ and measured at $670 \mathrm{~nm}$ in the ratio mode to compensate for source fluctuations. Fluorescence was quantified in arbitrary linear units. A steady-state fluorescence was reached within $10 \mathrm{~min}$, at which time cells were added to the cuvette $\left(10^{9}\right.$ cells $\mathrm{ml}^{-1}$ final concentration), and a new steady-state level of fluorescence was reached within $3 \mathrm{~min}$. Additions of inhibitors were made as indicated and their effects on fluorescence were determined.

Glucose accumulation. Cells were prepared as described above. Motility of wild-type cells was inhibited before accumulation assays where indicated. Accumulation assay mixtures $(1.0 \mathrm{ml})$ contained $5 \mathrm{~mm}-\mathrm{PB}, 1.5 \times 10^{9}$ cells and $100 \mu \mathrm{M}-\left[{ }^{14} \mathrm{C}\right.$ ]glucose [specific activity $50 \mu \mathrm{Ci}(1850 \mathrm{kBq}) \mu \mathrm{mol}^{-1}$ ]. Before the addition of glucose, the assay mixture was incubated at $25^{\circ} \mathrm{C}$ and vigorously aerated with water-saturated oxygen for 2 min. Samples $(100 \mu \mathrm{l})$ were removed $30,60,90,180$ and $300 \mathrm{~s}$ after adding $\left[{ }^{4} \mathrm{C}\right]$ glucose, and each sample was diluted in $4 \mathrm{ml} \mathrm{PB}$ and 
rapidly filtered through a Millipore HAWP $(0.45 \mu \mathrm{m})$ membrane filter. The filters were washed with an additional $4 \mathrm{ml} \mathrm{PB}$ and then placed into $5 \mathrm{ml}$ Aquassure. Radioactivity was determined using a Packard Tricarb 4530 liquid scintillation spectrometer.

Protein determination. Protein was assayed with the Bio-Rad protein assay kit (Bradford, 1976).

\section{RESULTS}

\section{Effects of inhibitors on gliding motility}

Wild-type cells of $C$. johnsonae grown in EC broth at $25^{\circ} \mathrm{C}$, harvested during the late exponential phase of growth and resuspended in PB were actively motile as determined by phase-contrast microscopy. Most cells in such a suspension attached to glass slides and made translocational, spinning, pivoting or somersaulting movements. Cells remained actively motile for more than $4 \mathrm{~h}$ when maintained on ice. Cells maintained at $25^{\circ} \mathrm{C}$ remained actively motile for at least $1 \mathrm{~h}$, and some cells still moved up to $3 \mathrm{~h}$ later.

All the chemicals tested stopped discernible movements of wild-type cells. Treatment of cells with CCCP $(10 \mu \mathrm{M}$ final concentration) or gramicidin $(50 \mu \mathrm{M}$ final concentration) immediately stopped movement. Treatment with sodium cyanide ( $10 \mu \mathrm{M}$ final concentration) or sodium azide ( $30 \mu \mathrm{M}$ final concentration) immediately stopped movement of most cells, but occasionally a slowly moving cell was observed up to 3 min after treatment, after which no movement was seen. When cells were treated with rose bengal $(4 \mu \mathrm{M}$ final concentration) or eosin Y $(0.32 \mathrm{mM}$ final concentration), cell movement slowed and eventually stopped within 14 min when using the light source available on the Zeiss Photomicroscope III (a $12 \mathrm{~V}, 60 \mathrm{~W}$ tungsten-halogen lamp run at $9 \mathrm{~V}$ and focused by a phase-contrast condenser). If a Kodak Wratten gelatin filter (no. 24, red) was inserted in the light path, cells remained motile for at least $1 \mathrm{~h}$ (the longest period monitored). Since measurements of adhesion, phage adsorption and glucose accumulation required larger quantities of cells, it was necessary to use an alternative light source for activating rose bengal and eosin $Y$. For these experiments, either rose bengal or eosin Y $(0.004$ and $0.32 \mathrm{~mm}$ final concentrations, respectively) were added to $25 \mathrm{ml}$ cell suspension in $125 \mathrm{ml}$ Erlenmeyer flasks illuminated by the $300 \mathrm{~W}, 120 \mathrm{~V}$ tungsten-halogen lamp of an overhead projector. A Plexiglass water cell, $10 \mathrm{~mm}$ deep, was inserted in the light path in order to maintain the temperature of the flasks at approximately $25^{\circ} \mathrm{C}$. Under these conditions, all cell movement stopped within 6 min of placing treated cells in the light path.

\section{Effects of inhibitors on adherence of cells to SHA}

Curves showing kinetics of adherence of wild-type cells, of wild-type cells whose motility was inhibited by CCCP, and of cells of the TNM mutant strain UW1029 are shown in Fig. 1. At all cell concentrations tested, greater numbers of untreated wild-type cells adhered to SHA beads than did nonmotile wild-type cells or cells of the TNM mutant. Results with untreated wild-type cells were typical of type I (Langmuir type) isotherms, i.e. a rapid increase in the number of attached cells occurs with increasing cell concentrations up to a limiting value, which indicates saturation of the available binding sites. The maximum number of binding sites $(N)$ per $40 \mathrm{mg}$ substrate and the affinity constant $(K)$ were calculated from measurements of the adsorption isotherm using the linear transformation $C / Q=1 / K N+C / N$, in which $C=$ concentration of free cells at equilibrium, $Q=$ cells bound to substrate, $K=$ the affinity constant, and $N=$ maximum number of binding sites (Gibbons et al., 1976). $K$ was $1.2 \times 10^{-10} \mathrm{ml} \mathrm{cell}^{-1}, N$ was 1.5 $\times 10^{9}(40 \mathrm{mg} \mathrm{SHA})^{-1}$, and the correlation coefficient for the line was 0.93 . A similar transformation of the data obtained with cells of the CCCP-treated wild-type or of the TNM mutant resulted in lines with extremely low correlation coefficients $(0.42$ and 0.31 , respectively) and therefore $K$ and $N$ were not calculated for these cells.

All treatments that inhibited motility also reduced adherence of wild-type cells to SHA (Table 1). Differences in adherence between treated and untreated wild-type cells were statistically discernible at the $2 \%$ level. Statistically significant differences in adherence were not discernible at the $2 \%$ level between motility-inhibited wild-type cells (treated with rose bengal, eosin $\mathrm{Y}$, CCCP, cyanide or azide) and cells of the TNM mutant. 


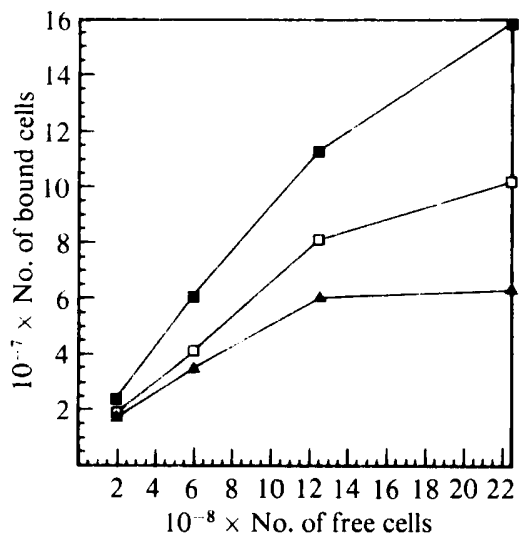

Fig. 1. Adhesion of motile wild-type cells ( $\square$ ), nonmotile wild-type cells $(\square)$ and cells of a TNM mutant $(\boldsymbol{\Delta})$ to SHA beads at various cell concentrations. Motility of wild-type cells was inhibited by pre-treating cells with $10 \mu \mathrm{M}-\mathrm{CCCP}$ for $5 \mathrm{~min}$. All assay mixtures were incubated for $10 \mathrm{~min}$ with constant mixing at $25^{\circ} \mathrm{C}$. Each point represents the mean of triplicate measurements, none of which varied by more than $21^{\circ}$ and usually less than $12 \%$.

Table 1. Adherence of motile and nonmotile cells of $C$. johnsonae to spheroidal hydroxyapatite

Adherence to SHA beads was assayed as described in Methods. Cells $\left(1.5 \times 10^{4} \mathrm{ml}^{-1}\right)$ were pre-treated with the indicated inhibitor until they were nonmotile as determined by phase-contrast microscopy and then used in adherence experiments $(1 \mathrm{ml}$ cells added to $40 \mathrm{mg} \mathrm{SHA}$ ). The values are means of three independent experiments $\pm \mathrm{SD}$

\begin{tabular}{clc} 
Phenotype* & \multicolumn{1}{c}{ Treatment } & $\begin{array}{c}\text { Percentage of } \\
\text { cells bound } \\
\text { to beads }\end{array}$ \\
W & Untreated & $7 \cdot 3 \pm 1 \cdot 1$ \\
& CCCP & $4 \cdot 5 \pm 0 \cdot 8$ \\
& Azide & $3 \cdot 2 \pm 0 \cdot 5$ \\
& Cyanide & $3 \cdot 0 \pm 0 \cdot 6$ \\
& Rose bengal + light & $3 \cdot 1 \pm 0 \cdot 2$ \\
TNM & Eosin Y + light & $3 \cdot 6 \pm 0 \cdot 4$ \\
& Untreated & $3.2 \pm 0.6$
\end{tabular}

*W, wild-type; TNM, truly nonmotile (strain UW1029).

\section{Effects of inhibitors on phage adsorption}

Curves showing kinetics of adsorption of $\phi \mathrm{Cj1} 3$ and $\phi \mathrm{Cj} 54$ to cells of the TNM mutant UW 1029, of the motile wild-type, and of the CCCP-treated (nonmotile) wild-type are shown in Fig. 2(a,b). Apparent adsorption rate constants for $\phi \mathrm{Cj} 13$ and $\phi \mathrm{Cj} 54$, calculated from these curves and from results obtained using wild-type cells whose motility was inhibited using the other chemicals tested are shown in Table 2 . All of the chemicals that inhibit motility reduced the adsorption rate of both phages from that seen with untreated wild-type cells to the level observed with the TNM mutant.

\section{Detection of membrane potentials}

Use of radivactive probes. Unsuccessful attempts were made to measure a p.m.f. of cells of the TNM mutant and of the wild-type with $\left[{ }^{3} \mathrm{H}\right] \mathrm{TPP}^{+}$and $\left[{ }^{14} \mathrm{C}\right]$ salicylic acid as probes and using cells centrifuged through silicone oil before and after treatment with CCCP. In four independent experiments, treatment of wild-type cells with $10 \mu \mathrm{M}-\mathrm{CCCP}$ did not cause a significant change in the concentration of weak acid associated with sedimented cells, and, 


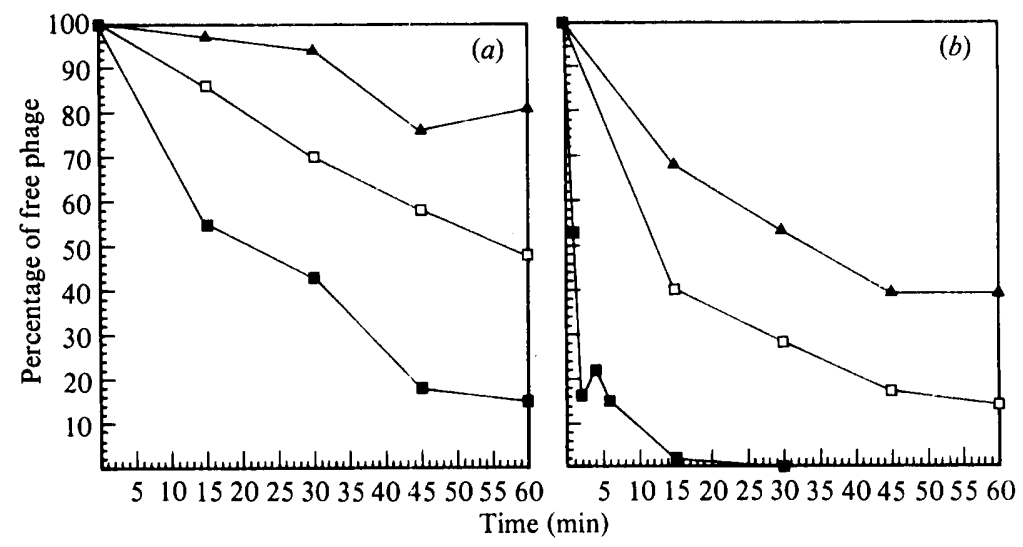

Fig. 2. Adsorption of phage to motile wild-type cells $(\boldsymbol{\square})$, nonmotile wild-type cells $(\square)$ and cells of a TNM mutant (A). All adsorption experiments were done in PB at $25^{\circ} \mathrm{C}$. Motility of wild-type cells was inhibited by pre-treating wild-type cells with $10 \mu \mathrm{M}$-CCCP for $5 \mathrm{~min}$. Nonadsorbed, free-phage titres are represented as percentages of zero-time titres. (a) Adsorption of $\phi \mathrm{Cj} 13$. (b) Adsorption of $\phi \mathrm{Cj} 54$. The $100 \%$ values (p.f.u. $\mathrm{m}^{-1}$ ) were $1.3 \times 10^{8}$ for phage $\phi \mathrm{Cj} 13$ and $1.7 \times 10^{8}$ for phage $\phi \mathrm{Cj} 54$. Each point represents the mean from two titre plates. Variation between duplicate plates was usually less than $9 \%$ and never more than $19 \%$.

Table 2. Adsorption of phages to motile and nonmotile cells of $C$. johnsonae

Cells $\left(1.5 \times 10^{9} \mathrm{ml}^{-1}\right)$ were pre-treated with the indicated inhibitor until they were nonmotile as determined by phase-contrast microscopy and then used in phage adsorption experiments.

\begin{tabular}{clcc} 
& & \multicolumn{2}{c}{$\begin{array}{c}\text { Adsorption rate constant } \\
\text { per min } \dagger\end{array}$} \\
Phenotype & \multicolumn{1}{c}{ Treatment } & $\overbrace{\phi \mathrm{Cj} 13}$ & $\phi \mathrm{Cj} 54$ \\
W & Untreated & 0.03 & 0.45 \\
& CCCP & $<0.01$ & 0.07 \\
& Azide & $<0.01$ & 0.08 \\
& Cyanide & $<0.01$ & 0.03 \\
& Rose bengal + light & $<0.01$ & 0.06 \\
ENM & $<0.01$ & 0.04 \\
TNM & Untreated & $<0.01$ & 0.03
\end{tabular}

* W, wild-type; TNM, truly nonmotile (strain UW1029).

+ Rate constant $=\ln 2\left(t_{1 / 2}\right)^{-1}$. The value of $<0.01$ indicates that adsorption of $50 \%$ of the phage did not occur within $60 \mathrm{~min}$ (the longest time period assayed).

instead of the expected decrease in concentration of $\left[{ }^{3} \mathrm{H}\right] \mathrm{TPP}+$ associated with CCCP-treated sedimented cells, approximately a twofold increase was observed. With cells of the TNM mutant, CCCP treatment caused no change in concentration of either probe associated with sedimented cells. Using the same procedure and materials, the oil centrifugation method for determining membrane potential was successfully applied to cells of Clostridium pasteurianum and Sarcina ventriculi (data not shown), showing that the results with $C$. johnsonae were due to peculiarities of the organism and not to misapplication of the method.

Use of a fluorescent probe. Addition of wild-type or TNM cells to a cuvette containing diSC $\mathrm{C}_{3}$ caused an immediate decrease in fluorescence, and a new steady-state level of fluorescence was 
Table 3. Shift in fluorescence of 3,3'-dipropylthiadicarbocyanine iodine caused by chemical treatment of cells

Fluorescence of diSC $_{3}$ was excited at $655 \mathrm{~nm}$ and measured at $670 \mathrm{~nm}$. The contents of the quartz cuvettes were stirred continuously and maintained at $25^{\circ} \mathrm{C}$. Cells and chemicals were added to $2 \mathrm{ml}$ dye solution $\left(1 \mu \mathrm{g} \mathrm{PB} \mathrm{ml}^{-1}\right)$ in the order indicated. Cells were always added to a final concentration of $10^{9}$ cells $\mathrm{ml}^{-1}$. Final concentrations of chemicals are indicated in parentheses. Initial steady-state fluorescence was reached within $10 \mathrm{~min}$. After addition of cells, the new steady-state level was reached within $3 \mathrm{~min}$. Subsequent to chemical treatments, steady-state levels were determined approximately $3 \mathrm{~min}$ after the time required for inhibition of motility by the indicated chemicals.

\section{Treatment

Steady-state
fluorescence
change*

1. None

+ Wild-type cells

+ Azide (30 mM)

+ Azide (60 mM)

+ Azide (90 mM)

2. None

+ Wild-type cells

+ Cyanide (10 mM)

+ Cyanide (20 mM)

+ Azide (60 mM)

3. None

+ Wild-type cells

+ Gramicidin $(150 \mu \mathrm{g})$

+ Gramicidin $(300 \mu \mathrm{g})$

+ Azide (60 mM)

\section{6}

18

26

41

42

50

27

24

24

41

50

23

37

45

47

$$
\begin{aligned}
& -38 \\
& -30(+8) \\
& -15(+15) \\
& -14(+1) \\
& -23 \\
& -26(-3) \\
& -26(0) \\
& -9 \quad(+17) \\
& -27 \\
& -1.3(+14) \\
& -5 \quad(+8) \\
& -3 \quad(+2)
\end{aligned}
$$

$\begin{array}{cl}\begin{array}{c}\text { Steady-state } \\ \text { fluorescence }\end{array} & \begin{array}{l}\text { Fluorescence } \\ \text { change* }\end{array} \\ 58 & \\ 20 & -38 \\ 34 & -24(+14) \\ 46 & -12(+12) \\ 45 & -13(+1) \\ 50 & \\ 24 & -26 \\ 22 & -28(-2) \\ 24 & -26(+2) \\ 42 & -8(+18) \\ 50 & \\ 24 & -26 \\ 33 & -17(+9) \\ 42 & -8(+9) \\ 43 & -7 \quad(+1)\end{array}$

* Numbers indicate the change in fluorescence from the initial measurement. Numbers in parentheses indicate the change from the steady-state fluorescence achieved with previous treatment. The results are from a single experiment. Every condition was tested at least twice. Although numerical values differed from one experiment to another, the patterns shown in this experiment were always the same.

obtained within $3 \mathrm{~min}$ (Table 3). The magnitude of the decrease was approximately the same when either TNM or wild-type cells were added, indicating that the electrical potential generated by mutant cells is the same as that of wild-type cells. Addition of either gramicidin or azide to these cell suspensions caused an increase in fluorescence, indicating dissipation of the electrical potential. The concentrations of these chemicals required for maximal increase in fluorescence of the probe were greater than those required to inhibit motility of wild-type cells. Addition of cyanide ( $20 \mathrm{~mm}$ final concentration) to a cuvette containing a suspension of either wild-type or TNM cells and the fluorescent probe did not cause a change in fluorescence. Subsequent addition of either gramicidin or azide (results for gramicidin are not shown) caused an increase in fluorescence, indicating that the cells maintained an electrical potential in the presence of cyanide. The effects on the electrical potential of cells of CCCP, rose bengal and eosin $\mathrm{Y}$ could not be determined using this technique due to quenching by these chemicals of the fluorescence of $\operatorname{diSC}_{3}$, even in the absence of cells (data not shown).

\section{Effects of motility inhibitors on glucose accumulation}

Glucose was accumulated over a 5 min time course by TNM cells at a constant rate of $6 \cdot 1 \times$ $10^{-2} \mathrm{nmol}(\mu \mathrm{g} \text { protein })^{-1} \mathrm{~s}^{-1}$ and by wild-type cells at a constant rate of $7.3 \times 10^{-2} \mathrm{nmol}(\mu \mathrm{g}$ protein $)^{-1} \mathrm{~s}^{-1}$ (Fig. 3). Pre-treatment of wild-type or TNM cells with $10 \mu \mathrm{M}$-CCCP completely eliminated accumulation of glucose (Fig. 3). All of the other inhibitors of motility tested (photoactivated rose bengal, eosin Y, cyanide and azide) also eliminated glucose accumulation by wild-type cells (data not shown). The effects of these chemicals on accumulation of glucose by TNM cells were not determined. 


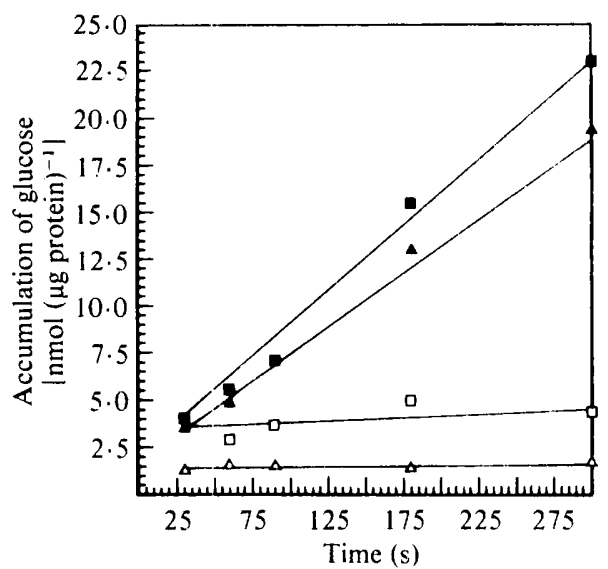

Fig. 3. Accumulation of glucose by cells of C. johnsonae. Reaction mixtures contained per ml PB: $1 \cdot 5 \times$ $10^{19}$ cells and $100 \mu \mathrm{M}-\left[^{1+} \mathrm{C}\right] \mathrm{glucose}$. The rates of accumulation were calculated from slopes of the lines determined by the least-squares method. $\mathbf{\square}$, Wild-type cells; $\square$, wild-type cells pre-treated for $5 \mathrm{~min}$ with $10 \mu \mathrm{M}-\mathrm{CCCP} ; \triangle$. TNM cells: $\triangle$. TNM cells pre-treated for $5 \mathrm{~min}$ with $10 \mu \mathrm{M}-\mathrm{CCCP}$. Results are from a single experiment, with each point representing a single measurement. Similar results were obtained in an independent experiment.

\section{DISCUSSION}

Motility-inhibited wild-type cells behave like cells of TNM mutants with respect to phage adsorption and adherence to SHA. Earlier results (Pate et al., 1979: Chang et al., 1984; Wolkin \& Pate, 1985) suggested that the TNM pleiotropy is produced by any condition that stops motility. Three approaches to test this idea are : (i) to isolate and test many TNM mutants; (ii) to attempt to isolate phages that will infect TNM mutants: and (iii) to determine whether inhibiting motility of wild-type cells induces the TNM pleiotropy. Most mutations that can block motility should be represented in a large collection of TNM mutants. If all mutants in such a collection show the pleiotropy, the implication is that whatever blocks motility results in the pleiotropy. If all TNM mutants are missing a specific cell surface component required for both motility and phage adsorption, then there should exist phages that adsorb to different receptors. Such phages should infect TNM mutants and a large collection of phages against wild-type cells should include such phages. And, finally, all chemicals that stop motility should also block phage adsorption and cell adherence only if these processes are motility-dependent. They should not block phage adsorption and cell adherence if these processes are not motility-dependent, but only depend on a specific surface component missing from all TNM mutants. The argument would be strengthened if the inhibitors each have a different primary target, avoiding the possibility that a specific inhibitor alters a particular surface component or blocks production of an intermediate needed for motility, phage adsorption and cell adherence, and avoiding the possibility that secondary effects of an inhibitor block all three processes independently by affecting a variety of different cell surface components separately. If different inhibitors with different properties are used, secondary effects of one are unlikely to be the same as those of another. If the TNM pleiotropy is due not to the dependence of expression of the affected properties on motility but to the dependence of expression of motility and other characteristics of the pleiotropy on a cellular component or intermediate that is affected by an inhibitor, then among a variety of inhibitors, each with different properties, there should be one that stops motility without affecting the common component.

The work reported here completes the three experimental approaches discussed above to test the motility dependence of characteristics associated with the TNM pleiotropy. Over 250 TNM mutants derived from strain UW101 have been isolated by using four different selection procedures and all exhibit the TNM pleiotropy (Pate et al., 1979; Chang et al., 1984; Wolkin \& Pate, 1985; and unpublished data). Differences among the mutants are evident from differing 
patterns of membrane proteins on SDS-polyacrylamide gels (unpublished data), showing that the mutants were not all the result of mutations causing the same defect. A total of 36 independent isolates of $C$. johnsonae have been tested, and all TNM mutants derived from these strains were also resistant to all phages that infect parental strains (Chang et al., 1984). All attempts to isolate phages that will infect TNM mutants have failed (Pate et al., 1979: Chang et al.. 1984: Wolkin \& Pate, 1985). There are now in our collection 45 independently isolated phages active against cells of strain UW101. Among these, at least 30 different host-range patterns have been demonstrated using independent isolates of $C$. johnsonae and motile, phageresistant mutants, indicating that not all phages use the same infection site. Therefore, the pleiotropy cannot be explained by the loss or alteration of a specific surface molecule that serves as receptor for all phages and as a component of the motility machinery. And now we have shown that all chemical inhibitors that stop motility also interfere with phage adsorption and cell adherence. The ideal inhibitor for these studies would affect motility specifically, leaving p.m.f. and glucose transport properties unchanged and making interpretations of the results more straightforward. Although none of the inhibitors used was specific for motility, the results, when considered along with properties of TNM mutants, provide a strong argument for the motility-dependence of phage adsorption and cell adherence.

What is the relationship of motility with the characteristics affected in TNM mutants or by chemical inhibitors? The answer to this question must take into account the observations (i) that TNM mutants all show the same pleiotropy and all generate and maintain p.m.f. and transport glucose, and (ii) all chemical inhibitors of motility affected the two properties used as an index of the pleiotropy but also blocked glucose transport and p.m.f. These observations suggest that all inhibitors stopped motility by causing depletion of p.m.f., which inhibited both glucose transport and motility, which in turn blocked phage adsorption and cell adherence. In Fig. 4 are three representations of possible relationships of motility and p.m.f. with phage adsorption, cell adherence and glucose transport. Fig. 4(a) shows p.m.f. as the required energy source for both motility and glucose transport. The expression of characteristics associated with the TNM pleiotropy does not require p.m.f. directly, but does require that cells are motile. As shown. all mutations blocking motility would exhibit the TNM pleiotropy, as was actually observed in nonmotile mutants. Some mutations (dashed arrow) would result in mutants more severely pleiotropic than those actually obtained, being unable to generate a p.m.f. Fig. $4(b)$ shows all affected characteristics as directly requiring a p.m.f., explaining the observed effects of chemical inhibitors but not explaining the pleiotropy of TNM mutants. Mutations resulting in nonmotile mutants (dashed arrows) would not have the TNM pleiotropy actually observed. They either would be defective only in motility or would be incapable of generating a p.m.f. and incapable of glucose transport, as well as expressing the TNM pleiotropy. Fig. 4(c) shows only motility and glucose transport are dependent on p.m.f., and phage adsorption and cell adherence are independent of motility. To explain the actual effects of chemical inhibitors, it must be assumed that, in addition to depleting p.m.f., nonspecific effects of all five inhibitors block both phage adsorption and cell adherence separately. According to this scheme, a nonmotile mutant (dashed arrows) would not exhibit the TNM pleiotropy. Of the three schemes depicted, only that in Fig. 4(a) explains both the effects of chemical inhibitors on wild-type cells and the pleiotropy of TNM mutants.

Since the goal of the present work was to determine if stopping motility of wild-type cells is sufficient to interfere with phage adsorption and cell adherence. a chemical that specifically inhibits motility would have been extremely useful. Therefore, we wished to determine whether TNM mutant cells and chemical-treated wild-type cells maintained a p.m.f., in order to answer the question is the TNM pleiotropy due to the nonmotile condition or to depletion of the p.m.f.? Problems encountered with the three different procedures for measuring membrane potential prevented unequivocal determination of membrane potentials in cells after treatment with certain inhibitors. But the information obtained was sufficient to show that the TNM pleiotropy is manifested in cells that maintain a normal potential but are nonmotile (TNM mutants), and that whenever the potential is eliminated, glucose transport is blocked. Therefore, the TNM pleiotropy is not correlated with loss of membrane potential but with the inability of cells to move. 

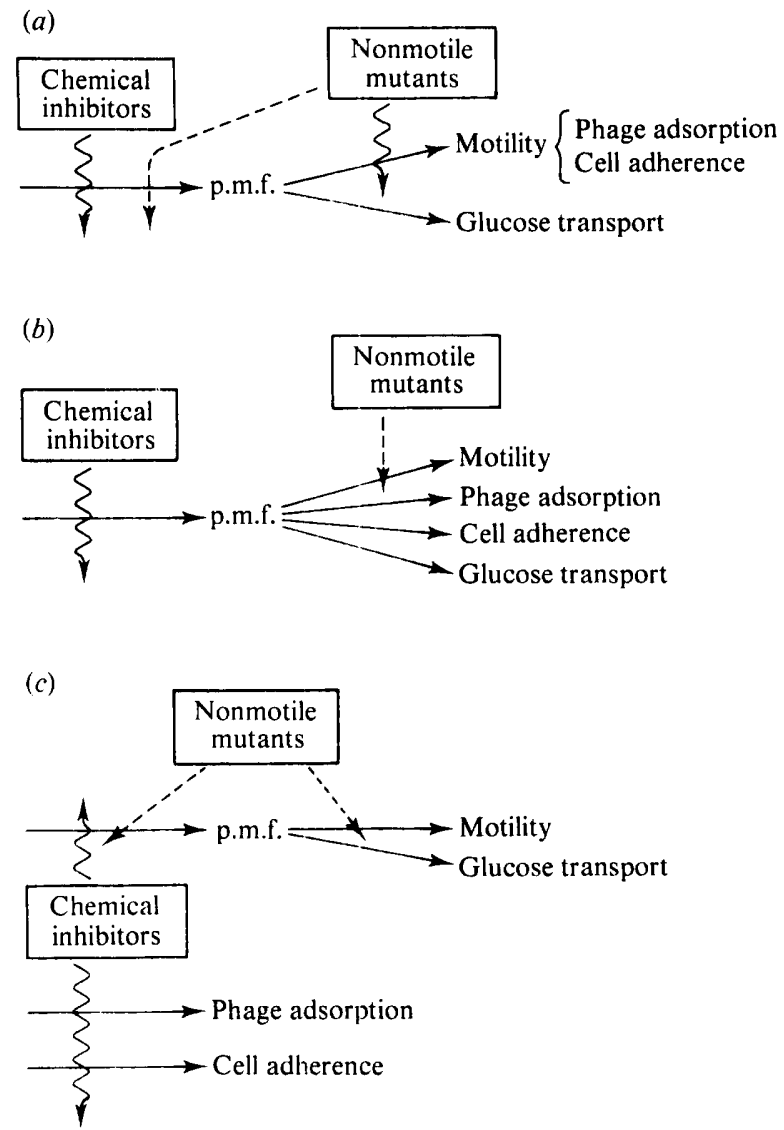

Fig. 4. Three representations of possible relationships of motility and p.m.f. with phage adsorption, cell adherence and glucose transport. Expression of one property is shown as being necessary for expression of another by an arrow leading from the necessary to the dependent property. Wavy arrows show sites where chemicals or mutations could act to block motility while also blocking expression of those properties affected by chemical inhibitors and those affected in all TNM mutants. Dashed arrows indicate sites where mutations could act to produce types of nonmotile mutants never observed in our collection, those that are incapable of generating a p.m.f. and would be transport defective, or those that are unchanged with respect to phage adsorption and cell adherence. As discussed in the text, characteristics of inhibitor-treated cells and of TNM mutants favour the scheme shown in $(a)$ over those shown in $(b)$ and $(c)$.

Although difficulties with the methods used prevented us from assaying the p.m.f. of all treated cells, some of the problems themselves are of interest, because they seem to be peculiar to $C$. johnsonae and are probably due to properties of the cell surface that are dependent on moving surface components of this bacterium. Chang (1982), using $\left[{ }^{3} \mathrm{H}\right] \mathrm{TPP}^{+}$in a flow-dialysis system, demonstrated an electrical potential of approximately $-110 \mathrm{mV}$ in wild-type cells t detected no potential in cells of any TNM mutants tested. Since growth rates and yields of wutant cells were the same as those of wild-type cells, it was concluded that mutant cells generated membrane potentials that the method failed to measure, possibly because their surfaces were less hydrophobic than wild-type surfaces and poorly permeable to the lipophilic cation TPP ${ }^{+}$. The prediction of less hydrophobic cell surfaces of TNM mutants was later verified (Wolkin \& Pate, 1985), and this property was shown to be part of the TNM pleiotropy characteristic of all TNM mutants. A similar problem may underlie our failure to measure a membrane potential in wild-type or mutant cells using TPP ${ }^{+}$in the silicone oil centrifugation method. Kashket (1981 $a$, b) showed that centrifugation of cells through silicone oil can lead to lower estimates for total 
p.m.f. compared with values obtained using other procedures. She suggested that oxygen limitation during centrifugation of control cells through silicone oil causes loss of accumulated $\mathrm{TPP}^{+}$, which would result in a lower estimate of TPP ${ }^{+}$lost from experimental cells than had actually occurred. Perhaps the same problem is magnified in cells of $C$. johnsonae due to their cell surfaces becoming more hydrophilic and less permeable to TPP ${ }^{+}$when motility is stopped by addition of CCCP. Loss of accumulated $\mathrm{TPP}^{+}$from control cells may be rapid on becoming oxygen-depleted, while loss of accumulated $\mathrm{TPP}^{+}$from CCCP-treated cells may occur at a slower rate due to the immediate cessation of motility upon addition of CCCP. These results would combine to give the false appearance of increased accumulation of $\mathrm{TPP}^{+}$by $\mathrm{CCCP}$ treated cells.

Application of the fluorescent probe $\mathrm{diSC}_{3}$ to measurement of membrane potential was as effective with TNM mutants as with wild-type cells, showing that altered surface characteristics associated with the nonmotile condition do not interfere with the use of this probe to measure membrane potential. Likewise, the assay for CCCP-sensitive glucose accumulation as an indicator of membrane potential was applicable to cells of both the wild-type and TNM mutant, but there were difficulties in applying either of these methods to cells treated with either of the photoactivated dyes eosin $\mathrm{Y}$ and rose bengal. Both dyes quench fluorescence emitted by the fluorescent probe, preventing determination of the membrane potential. Inhibition of glucose accumulation in cells treated with either of these dyes could be due to failure of treated cells to maintain a p.m.f. or to effects of the dyes on glucose transport. We cannot yet distinguish between these possibilities, and published reports on effects of these dyes in other systems suggest that one possibility is as likely as the other. Both eosin Y and rose bengal react with thiol, methionyl, indole and amino groups, in addition to imidazole groups (Means \& Feeney, 1971), suggesting that their actions would not be very specific. Even the low concentrations we used were lethal to cells of $C$. johnsonae (data not shown). Motility of Streptococcus sp. strain V4051 was reported (Conley \& Berg, 1984) to be inhibited by both eosin Y and rose bengal by reaction of photoactivated dyes directly with proteins of flagellar rotary motors. This conclusion was based partly on the observation that treated cells did not recover the ability to move upon reestablishing the p.m.f. in the form of a potassium diffusion potential, indicating that the dyes inactivated the motors rather than dissipating the membrane potential. They also showed, using valinomycin-induced rubidium uptake, that the diffusion potential developed by eosin-treated cells should have been sufficient to turn the rotors, being only about $30 \%$ lower than that developed by untreated cells. Reagents that react with imidazole groups have also been shown to block solute transport systems. Diethylpyrocarbonate was reported to uncouple the lactoseproton symport system from the proton gradient without affecting maintenance of a membrane potential by cells of Escherichia coli (Padan et al., 1979). But rose bengal inhibited both lactose transport and generation of the p.m.f. in E. coli membrane vesicles (Garcia et al., 1982). Thus, the effects of eosin $\mathrm{Y}$ and rose bengal will probably be varied to depend on both the organism and the experimental conditions used.

Finally, the unexpected results with cyanide-treated cells remain unexplained. Cyanide is expected to prevent respiration-dependent generation of the p.m.f. (Harold, 1972, 1977), and the cyanide-induced inhibition of both motility and glucose transport in $C$. johnsonae could be explained by a loss of p.m.f. Using a Yellow Springs Instrument Co. model 53 oxygen electrode, we determined that cyanide ( $10 \mathrm{~mm}$ final concentration) stops oxygen consumption within $30 \mathrm{~s}$ (data not shown), indicating that, as expected, cyanide acts as a respiratory poison in this organism. However, exposure of cells to cyanide, even at a twofold higher concentration than that required to stop motility, did not cause loss of an electrical potential as measured with diSC $_{3}$ fluorescence. Use of this technique showed a loss of electrical potential in cyanide-treated cells upon addition of either gramicidin or azide, indicating that cyanide did not interfere with the measurement of electrical potential using $\mathrm{diSC}_{3}$ and that cells treated with cyanide alone maintained a potential that was destroyed by gramicidin or azide. The maintenance of an electrical potential in the presence of inhibiting levels of cyanide could be achieved by a protontranslocating ATPase, but in this case motility and glucose transport should not be inhibited. The results suggest that in $C$. johnsonae, under the experimental conditions used here, when 
generation of the respiration-dependent p.m.f. is blocked with cyanide, the cells still maintain an electrical potential that can be measured with the fluorescent probe but that cannot drive motility or glucose transport. A less likely explanation is that in $C$. johnsonae inhibition of motility and glucose transport by cyanide is due to nonspecific secondary effects of this inhibitor. These are questions that need to be explored in future experiments. It is interesting to note that gliding motility of Flexibacter BH3 was reported (Duxbury et al., 1980) to be stopped by the addition of cyanide, only to resurne at a much slower rate, suggesting to the authors that gliding motility in that organism can be energized by two different pathways, one resistant and one sensitive to cyanide.

The properties of cell adherence of $C$. johnsonae UW101 to SHA beads are similar to those reported for cells of two strains of oral Cytophaga sp. (Celesk \& London, 1980). Minor differences in experimental design could account for most differences observed. In each of our experiments the total number of cells available for attachment was $1.5 \times 10^{9}$ compared with about $7 \times 10^{8}$ using oral cytophagas, and the total amount of substrate available for attachment was $40 \mathrm{mg}$ SHA (C. johnsonae) and $20 \mathrm{mg}$ SHA (oral cytophagas). We chose conditions to give equilibration of free and attached cells after $10 \mathrm{~min}$ incubation (to be certain that cells remained motile); the equilibration period used with the oral cytophagas was $2 \mathrm{~h}$. The affinity constant for adherence was an order of magnitude lower using $C$. johnsonae $\left(1.2 \times 10^{-10}\right)$ than with the oral cytophagas $\left(1.5 \times 10^{-9}\right)$, and the number of substrate binding sites about three times higher using $C$. johnsonae. When calculated on the basis of $20 \mathrm{mg}$ SHA beads, the total number of binding sites is $7.5 \times 10^{8}$ using $C$. johnsonae and about $2.5 \times 10^{8}$ using the two strains of oral cytophagas, suggesting similar binding sites in all cases. The effect on adherence of stopping motility of the oral cytophagas was not investigated by Celesk \& London (1980), but they reported that pre-heating cells at $70^{\circ} \mathrm{C}$ (or higher) for $15 \mathrm{~min}$ reduced adherence by approximately $50 \%$. Such pre-heated cells would certainly be nonmotile, but whether this is the basis of inhibition of adherence is not obvious. The effects of other treatments on adherence to SHA, along with adherence properties of a non-coaggregating mutant of one of these strains led to the conclusion (Kagermeier et al., 1984) that adherence to SHA depends on somewhat nonspecific interactions between cells and SHA and probably involves multiple cell surface components. Results from our experiments using $C$. johnsonae are compatible with the idea of nonspecific interactions, not requiring cell movement and leading to poor adherence of cells to SHA, followed by a stronger adherence which can only be achieved by motile cells.

All the evidence is consistent with the idea that the TNM pleiotropy results from properties of the cell surface that are changed whenever motility is stopped, but the basis of the remarkable influence of motility on several seemingly unrelated properties of the cell surface is not understood. One explanation suggested pre viously (Chang et al., 1984; Wolkin \& Pate, 1985) is that the surface slime of these cells confers different properties upon the cell surface, depending on whether the slime is kept in motion by the action of the motility machinery or is static, when motility is inhibited. Predictions based on this idea can be tested experimentally. Whether this or some other explanation for the unusual motility-dependent properties of this bacterium proves to be correct, it seems likely that the answer will provide clues regarding the organization of cell surface components required for gliding motility.

This research was supported by the college of Agricultural and Life Sciences, University of Wisconsin, Madison, and by grant PCM-8316426 from the National Science Foundation. We thank David I Nelson of the Department of Biochemistry, University of $W$ isconsin, for advice and materials used in spectrofliorimetry.

\section{REFERENCES}

BRADFORD, M. (1976). A rapid and sensitive method for the quantification of microgram quantities of protein utilizing the principle of protein dye binding. Analytical Biochemistry 72, 248253.

CElesk, R. A.\& London, J. (1980). Attachment of or al Cltophaga species to hydroxyapatite-containing surfaces. Infection and Immunit! 29.768 777.
ChANG, L.-Y. E. (1982). Studtes on gliding motiliy in Cy tophaga johnsonac. PhD thesis, University of Wisconsin, Madison. USA.

(hang, L..-Y. E.. Pate, J. L. \& Betzig. R. J. (1984). Isolation and characterization of nonspreading mutants of the gliding bacterium Citophaga johnsomae Journal of Bacteriolog. 159, 2635 
Clark, W. B.. Bammann, L. L. \& Gibbons, R. J. (1978). Comparative estimates of bacterial affinities and adsorption sites on hydroxyapatite surfaces. Infertion and Immunity 19, 846-853.

CONLEY, P. M. \& BerG, C. H. (1984). (hemical modification of Streptococcus flagellar motors. Journal of Bacteriology' 158, 832-843.

Duxbury, T., Humphrey, B. A. \& Marshall, K. C. (1980). Continuous observations of bacterial gliding motility in a dialysis microchamber: the effects of inhibitors. Archives of Microbiology 124, $169-175$.

Garcia, M. L., Patel. L., Padan, E. \& Kaback, H. R. (1982). Mechanism of lactose transport in Escherichia coli membrane vesicles: evidence for the involvement of histidine residue(s) in the response of the lac carrier to the proton electrochemical gradient. Biochemistry 21, 58005805.

Gibbons, R. J., Moreno, E. C. \& Spinell, D. M. (1976). Model delineating the effects of a salivary pellicle on the adsorption of Streptococcus miteor onto hydroxyapatite. Infertion and Immunity 14, 1109-1112.

Glaser, J. \& Pate, J. L. (1973). Isolation and characterization of gliding motility mutants of Cytophaga columnaris. Archir für Mikrobiologie 93. 295-309.

HAROLD. F. M. (1972). Conservation and transformation of energy in bacterial memhranes. Bacteriological Revieu's 36, 172.230.

Harold, F. M. (1977). Ion currents and physiological functions in microorganisms. Annual Review of Microhiology 31, 181-203.

Kagermeier, A. S., London, J. \& Kolenbrander, P. E. (1984). Evidence for the participation of $\mathrm{N}$-acetylated amino sugars in the coaggregation between Cytophaga species strain DR2001 and Actinomices israelii PK 16. Infection and Immunity 44, $299-305$.
Kashiet. E. R. $(1981 a)$. Proton motive force in growing Streptococcus lactis and Staphylococcus aureus under aerobic and anaerobic conditions. Journal of Bacteriology 146, 369-376.

KASHKET, E. R. $(1981 b)$. Effects of aerobiosis and nitrogen source on the proton motive force in growing Escherichia coli and Klehsiella pnetumoniae cells. Journal of Bacteriology 146, 377- 384.

KashKet, E. R. \& BARKer, S. L. (1977). Effects of potassium ions on the electrical and $\mathrm{pH}$ gradients across the membrane of Streptococcus lactis cells. Journal of Bacteriolog! 130, 1017-1023.

Means, G. E. \& FeEney, R. E. (1971). Chemical Modification of Proteins. San Francisco: Holden-Day Inc.

Padan, F., Patel, L. \& Kaback, H. R. (1979). Effect of diethylpyrocarbonate on lactose/proton symport in Escherichia coli membrane vesicles. Proceedings of the National Academy of Sciences of the United States of America 76, 6221-6225.

Pate, J. L., Petzold, S. J. \& Chang, L.-Y. E. (1979). Phages for the gliding bacterium Cytophaga johnsonae that infect only motile cells. Current Microbiology 2, 257-262.

WAGgONER, A. S. (1979). The use of cyanine dyes for the determination of membrane potential in cells, organelles, and vesicles. Methods in Enzymology 55, 689-695.

Wolkin, R. H. \& PATE, J. L. (1984). Translocation of motile cells of the gliding bacterium Cytophaga johnsonae depends on a surface component that may be modified by sugars. Journal of General Microbiology 130, 2651-2669.

Wolkin, R. H. \& Pate, J. L. (1985). Selection for nonadherent or nonhydrophobic mutants co-selects for nonspreading mutants of Cytophaga johnsonae and other gliding bacteria. Journal of General Microbiology 131. 737-750. 